\title{
Increase for research funds leaves Austria below EU average
}

Munich. Austria's researchers have been given priority in the 1995 budget without even having to ask. Compared to an overall increase in the national budget of 2.8 per cent over 1994, research funding will increase by 6 per cent, to 2.89 billion Austrian schillings (US\$295 million).

The Fonds zur Förderung der Wissenschaftlichen Forschung (FWF), which provides money for university research, will receive a 10 per cent increase, to ÖS653 million.

While the average expenditure by European Union (EU) states on research is around 2 per cent of gross domestic product (GDP), Austria's is only 1.6 per cent. All parties want to see this increase. But, despite the increase in cash next year, research spending as a proportion of GDP is expected to fall because of high predicted growth, and the fact that industry is not expected significantly to raise its investment in research.

Rudolf Scholten, the science minister in the coalition government formed last January, said that, even though it is acceptable, the increase is "not generous". Arnold Schmidt, president of the FWF, puts the good fortunes of Austrian research in a more gloomy international light. "Everyone knows that our science budget is too low compared with, say, Germany, which is always an important yardstick for us", he says.

He points out that the Deutsche Forschungsgemeinschaft, the German research agency which is equivalent to the FWF, receives twice as much funding per capita of the general population as the FWF. It also has a guaranteed 5 per cent annual increase over the next few years. "Our ten per cent rise is $O K$, but we still have a lot of catching up to do", he says.

Scholten has announced plans to streamline research organizations in order to ensure a more efficient use of funds. $\mathrm{He}$ argues that Austria has too many small research groups, and that money cannot ,therefore, be concentrated on priorities.

He also plans to establish a special fund to provide direct support to young scientists. This is particularly important because the rigid Austrian system of promotion tends to give established professors excessive control over the careers of their young collaborators.

The 1995 budget also provides an aboveaverage 5.1 per cent increase in the general budget for universities, and allocates ÖS800 million to the EU's fourth Framework programme, which is now open to Austrian scientists following Austria's admission to the Union. Alison Abbott

\section{Swedish council is dismissed amid claims of malpractice}

London. The entire governing body of Sweden's state Medical Research Council (MFR) was dismissed by the government last week, amid controversy in the media over the allocation and use of research grants, partly a result of the relatively small size of the country's research community.

The 11-member council is responsible for distributing 330 million krone (US\$46 million) for medical research every year. The dismissal of its governing council follows a series of public accusations of malpractice, culminating last week with allegations that one of the council's long-serving members had awarded himself SEK4.2 million for research, some of which never took place.

Both the Swedish government and the council have ordered separate investigations into the affair, expected to be complete before the appointment of new council members - four of whom are chosen by the government, and the rest elected from Swedish medical researchers - on 23 May.

But the reconstituted council will have to do without the services of one of the country's leading scientists. Håkan Eriksson, a professor of reproductive endocrinology at the Karolinska Institute, resigned last Friday (28 April) after 18 years as assistant secretary of MFR's secretariat, apparently in protest at the way the government had bowed to media pressure in dismissing council members.

Olof Edhag, deputy director general of the National Board of Health and Welfare in Stockholm and one of the council members to be dismissed, agrees, saying that the MFR affair had become a victim of "too little analysis and too much vendetta".

The newspapers, he says, had sensed there was something wrong, but "were unable to properly evaluate the issue". Nonetheless, he adds, the government's decision to "exchange" MFR's council, was the best course of action. It is important that MFR's reputation in the eyes of the public be maintained."

The latest controversy centres on Rolf Öhman, professor of psychiatry at the University of Lund. He has been a member of MFR's Council for 12 years, and for the past three has chaired the subcommittee that allocates funds for research in psychiatry.

Recently, the Swedish daily newspaper, Svenska Dagbladet, the nation's secondlargest selling daily was handed a 250-page dossier on the psychiatry subcommittee's activities, by another psychiatrist at the university, Hans Bendz.

According to reports in the newspaper, the dossier allegedly shows that Öhman's committee apparently handed out SEK4.2 million in research funds between 1982 and
1994 for projects headed by Öhman himself. Some projects are alleged not to have existed, while others never got off the ground.

Öhman is also said to have submitted research grant applications on behalf of people who were unaware of their names being used. Two such applications were uncovered by Svenska Dagbladet. According to a journalist on the paper, on one application, "at least three of the 10 names listed as Öhman's collaborators" had not been told that their names were included.

Öhman has admitted in an interview with Svenska Dagbladet he may be partially at fault. But added that he was the victim of a system in need of reform. He has also defended his decision not to initiate research earmarked for funding, on the grounds that he had been too busy with other projects. He told the newspaper that he had, in fact, handed back SEK1.7 million that had not been used.

The allegations against Öhman, however, are the latest in a series of public controversies to hit the research council. Last year, it was learnt that the recipients of a SEK 28 million grant for genome research were indirectly associated with members of the subcommittee that handled their application. Despite criticism from Sweden's attorney general, the council refused to apologize.

Later the same year, two women researchers published findings suggesting that the council discriminates against women in appointing university assistant professors. In the national debate that ensued, Sweden's education minister Carl Tham joined calls for MFR to be censured by suggesting that women be appointed to senior positions "even if there are better qualified men" until their numbers equalize.

Both incidents have turned the spotlight on the MFR, and Sweden's medical researchers could have done without the resulting embarrassment. Many admit knowing of problems at MFR long before the current furore; one scientist at the Karolinska Institute, for example, says that, with a relatively small number of researchers - Sweden has only six universities - members of grant-approval committees often find themselves facing their own research applications. "The usual thing was to go out of the room when your own application came up," he says.

But the scientists blame "shallow and exaggerated press reporting", as well as the refusal of the research council to admit past mistakes, as having led to the present state of affairs. Many feel the issue has been badly handled. "It is very unfortunate for the whole of Swedish science," says one.

Ehsan Masood 